\title{
The Readability of E-module Material in Teaching English for Specific Purpose of Biology Education Study Program, Muhammadiyah University of Palembang
}

\author{
Tri Rositasari \\ Aceng Rahmat
}

Emzir

\begin{abstract}
This study was aimed to determine the E-module Material in Teaching English for Specific Purpose of Biology Education Study Program, Muhammadiyah University of Palembang. There are some aspects that became in indicators why module was created. One of them was to find out the readability of E-module material Teaching English for Specific Purpose of Biology Education Study Program. Therefore, this readability was tested from 3 aspects of evaluations, there were language component aspects, meaning, typing aspects, display, and publication aspects. Form all the aspects, it was found that the readability ofE-module Material in Teaching English for Specific Purpose of Biology Education Study Program, Muhammadiyah University of Palembang was effective.
\end{abstract}

\section{BACKGROUND}

Technology in education is an applied discipline, it develops because of the needs of the field, which is the need to learn more creative, more efficient, more, wider, faster and so forth. The effect of the use of technology is very influential in the process of learning the language itself apart from the role of an instructor in other words the cooperation between the use of technology with the role of a good instructor will produce better learning results.

In the process of learning English at the college level there is the concept of instructional strategies that should be directed at the liveliness of students, while the role of lecturers is as a motivator and facilitator. The role of lecturer as a motivator means to increase the spirit and development of learning activities. Lecturers should be able to motivate and provide encouragement and strengthening to dig the potential activities, and creativity owned by students so that there will be dynamics in the learning process. According to SyaifulBahri learning to teach as an instructional system refers to the sense as a set of interdependent components to each other to achieve goals. The Biology Education Study Program makes the English courses as one of the compulsory lecture materials provided in the hope of assisting them in the breathing of Biological terms adjacent to foreign languages as well as helping students to have good English skills to meet the requirements in global competition and the challenge of the world of work.

Therefore, the need for effective teaching materials, dynamic, in accordance with the needs of students accompanied by effective learning. Effective teaching is where the creation of learning situations in which an educator can transfer his or her knowledge well and effectively. One of them is to take advantage of technological developments. One of them is the utilization of Electronic Modula tau commonly known as E-Module. Based on the results of research conducted by I KomangPriatna states that the use of electronic modules in learning to get a 
very good response by students.Sharon (2018) added that learning module was a unit of learning that was designed for a used for a small not civic.

Researchers have observed the use of modules as teaching materials in Biology Education Study Program of Muhammadiyah University of Palembang through interviews, where the use of new modules started in 2012, some English lecturers who teach in Biology Education Study Program make the module as teaching materials must be used by students during the course, but this module does not meet the requirements as an independent learning facility, the contents of the module does not explain the material in detail and more clearly, the selection of reading topics that are not in accordance with their field in other words too general so that the use of vocabulary is still too common student difficulties in understanding the contents of the material and still desperately need explanation of lecturers to understand the material. In addition, there is still a lack of practice questions which students need to understand the material. Thus the existing module has not been intended in the category of independent learning, because as in the above statement that the module is a resource that is independent. In addition, in Biology Education Program, English courses only earn 2 credits in every week with 100 minutes time, therefore good modules should be able to adjust the time efficiency, and promote clearer material understanding so that students can understand the contents of the material independently.

In making the teaching materials in the form of e-module should also pay attention to various important things related to the feasibility of e-module, one of them is by knowing how readability of English e-module model for Biology special purpose. Hutchison (1987) ESP is a learning that was designed based on students' need. Belcher (2009) stated the objective of ESP was the main understanding of target language based on the students' need like for what and for who. A study conducted by Mitsunori defined ESP as an approach in language learning where all the material and method have been chosen based on student's need.

\section{METHOD}

The module in this study was developed based on student needs analysis. The analysis will be done by observing the various backgrounds and characteristics of the students. This module is tested to students in Biology Education Study Program semester 1 outside of college hours. This is because their new English courses can be in even semesters. Further evaluated, analyzed, and revised / developed to obtain maximum results. With the description of the material, the steps are easy to understand and the design, attractive appearance, is expected to be a positive indication of the upcoming student learning outcomes. And can boost the value of those who have been almost the majority of students get the value of $\mathrm{C}$. E-module that will be created by using a computer program known as Adobe Flash cs6 (editing e-module), Adobe Photoshop (image editing) and Adobe Audition (editing sound)

Module development of English teaching materials for Biology to be conducted researcher in this research is using Borg and Gall model. Researchers chose this model because the researcher considers that the model with this system approach in accordance with the underlying problems of this research. Given the needs analysis, look at the characteristics of students, with existing conditions / systems.the researcher hopes that this model can be developed e-module of English teaching material for the specific purpose of Biology that is valid, practical and effective in improving students' learning achievement in Biology Education Study Program. Research results from TienTien Lee, Kamissah Osman stated that the use of multimedia modules in learning can increase the value. 


\section{RESULTS AND DISCUSSIONS}

In electronic module English for Biology which has been designed in computer based form called prototype 1 , then prototype 1 is done self evaluation stage and expert review consisting of biology content expert, design expert and teaching English (construct) and expert media (layout). In addition, One-to-One evaluation, and small group evaluation and the last test of effectiveness. One of the things done is to know the legibility of e-modules that have been made. To find out the readability of e-module of English teaching material for Biology, the researcher distributed questionnaire to the respondents in small group trial which amounted to 15 people after small group trial experiment was conducted

\section{Aspects of Language Components and Meanings}

According to $73.3 \%$ of the vocabulary respondents present in English teaching materials for Biology in the form of e-modules are familiar with them. The opinion is very familiar with the vocabulary contained in English teaching material for Bilogi in the form of e-module as much as $26.6 \%$ of respondents. The vocabulary contained in English teaching materials for Biology is a vocabulary that is often used or related to the biological material itself according to $53.3 \%$ of respondents feel familiar while $46.6 \%$ of respondents said very familiar.

According to $86.6 \%$ of respondents argue that they are easy to understand the vocabulary meaning contained in the English teaching material for Biology in the form of this e-module and $13.3 \%$ of respondents answered that they are very easy to understand the meaning of the vocabulary contained in the material teach English for Biology. No respondent who answered did not understand the meaning of the vocabulary. According $46.6 \%$ of the grammatical respondents present in English teaching materials for Biology in the form of e-modules are familiar with them. The opinion is very familiar with the grammar contained in English teaching material for Bilogi in the form of e-module as much as $53.3 \%$ of respondents. Exercise questions in grammar in English for Biology teaching materials according to $60 \%$ of respondents feel easy to do while $40 \%$ of respondents said very very easy. Topics contained in English teaching materials for Biology is a topic that is often used or related to Biology material itself according to $60 \%$ of respondents feel familiar while $40 \%$ of respondents expressed familiar. According to $66.6 \%$ of the speaking material respondents contained in English teaching materials for Biology in the form of e-modules that are often used in general familiar to them. The opinion is very familiar with the speaking material contained in the English teaching material for Bilogi in the form of e-module as much as $13.3 \%$ responden.Latihan problem contained in listening material in English teaching materials for Biology according to $73.3 \%$ of respondents is very clear while $26.6 \%$ respondents stated that $93.3 \%$ of respondents argue that the command phrases in the exercise of questions in English teaching materials for Biology in the form ofe-module was very clear while $6.7 \%$ of respondents was clear.

\section{Typing and Display Aspects}

Based on the opinion of $86.6 \%$ of respondents stated that the display of letters on English teaching materials for biology in the form of e-module is very good and $13.3 \%$ stated good. As for the size of English teaching material letters for Biology in the form of e-module is very good according to $86.6 \%$ of respondents and $13.3 \%$ respenden declared good. Likewise, in terms of the type of letters used in the English teaching materials for Biology in the form of e-module 86.6 respondents argue very well and $13.3 \%$ stated good. In terms of drawings, the display of images on English teaching materials for Biology in the form of e-modules is very good according to $80 \%$ of respondents and $20 \%$ of respondents stated good. Similarly, in terms of display of tables on English teaching material for Biology in the form of e-module is very good according to $46.6 \%$ of respondents and $53.3 \%$ stated good .. As well as tables, the display of empty boxes to place an answer that exist in every training in English teaching material for 
Biology in the form of e-module is very good according to $53.3 \%$ while $46.6 \%$ of respondents think well.

\section{Aspects of Publication}

The condition of the next display is the condition of front page display / cover of English teaching material for Biology in the form of e-module according to $80 \%$ of respondents stated very good and 20\% stated good .. Then according to $46.6 \%$ respondents stated that the condition of display is very good $53.3 \%$ of respondents stated good. The order of sub-section of the material in English teaching material for Biology in the form of e-module according to 80\% of respondents stated very good, whereas according to $20 \%$ respondent think good.86.6\% of respondents stated that in the case of the subdivision of training exercises in English teaching materials for Biology in the form of e-module is very good and $13.3 \%$ of respondents think well.The last statement on the publication aspect is the printed condition on English teaching materials for Biology in the form of e-modules that categorize very well according to $86.6 \%$ of respondents and $13.3 \%$ of respondents stated good.

Based on the results of each step taken to measure the impact of the e-modules produced, one of which is to measure the readability of English e-modules for biology-specific purposes, the results of this study indicate that the teaching of English courses for Biology Education Studies Program by using electronic modules can improve the English language competence of Biology students. Therefore, the researcher recommends lecturers of English course subjects in Biology Education Program to use electronic module as an alternative teaching material in improving their competence and interest in learning to deepen the English language. The teaching materials in electronic form of this module can be used not only in Biology Education Study Program of Teacher Training and Education Faculty of Muhammadiyah University.

\section{CONCLUSSIONS AND SUGGESTIONS}

All the Biology Education students in Faculty of Teacher Training and Education, University of Muhammadiyah Palembang need an interesting, understandable learning material. The used module had minus and plus. The main plus was cover module was interesting and printed in small size so that was easy to be brought. Meanwhile, the main minus was in the content which does not explain the material detail, the chosen topic that does not correspond with its field. Furthermore, the less of exercise in the module also made the students hard to understand the material.The results of the developed model was based on analysis needs in the field. In Model prototype 1 e- module language teaching materials English for Biology composed from four skills, grammar, and useful exercise that made the students easier to understand the content. The validity of module content was tested in some stages; appropriateness test, try-out, one-toone and small group test. It was seen from score questionnaire obtained ie4, 39 with category good. On stage test try one-to-one, respondents give comment that electronic module already good although still there was repaired. In the test of small group it was found that E-module as teaching material could increase the biology education study program students' English competence. It could be seen from the increase students' comprehension that could be seen from pre-post test result. It was proved from the highest was $90 \%$ and the lowest was $40 \%$. In the small group try out, it was found thatmean prates $=40,00$ and mean pascates 69.27 .dengan $\mathrm{t}$-obtained $=22.040$.dannilait - table $=1,761$. dengan tarafsignifikansi 95\% $(\alpha=0,0,05)$. It means that $\mathrm{t}$-obtained was higher that $\mathrm{t}=$ table. The it could be concluded that Biology E-module could increase the Biology education study program.

According to user, language teaching materials English for Biology in form electronic module was good. 
1. According to readibilty language teaching materials English for Biology in form electronic module had goodquality. .

2. On test effectiveness, language teaching materials English for Biology in form electronic module proven could improve competence language English students of Study Program Education Biology. This could visible from enhancement score language English good on individual as well on groups. Enhancement sekor individual from prates to pascates the highest on test effectiveness is $100 \%$ and enhancement score Lowest is $62.8 \%$

On test effectiveness, mean prates 44,20 and post-test mean 79,56dengan $t$-count $=$ 45,289 dan value $t$-table $=2,797$ with level 95\% significance $(\alpha=0.0,05)$. This means value $t$ count more big from $t$-table. So could concluded that language teaching materials English for Biology shaped electronic module could increase competence language English students of Bilogy Education Study Program.

\section{BIBLIOGRAPHY}

BassmaBasheerNomass , The Impact of UsingTechnolgyin Teaching English as a Second Language, English Language and Literature Studies; Vol, 3, No. 1; 2013, ISSN 1925-4768 E-ISSN 1925-4776 (accessed October 20 , 2017).

Diane Belcher, English for Specific Purposes in Theory and Practice,Editor http:/www.press.umich.edu/titleDetailDesc.do?id=770237(Michigan ELT,2009), h.1.

${ }^{1}$ LenkaKucirkova,PetrKucera, Hana VostraVydrova, English for Specific Purposes E-Learningt Experimental Research.ERIES Journal vol.7 no 3-4, online ISSN 1803-1617, (diakses 8-Juni 2017).

Hasmimoto,Mitsunori, English for Specific Purposes and Teaching of Financial English (Kanagawa University Repository,1994), h.101.

HuiweiCai. E - Learning and English Teaching. IERI Procedia 2 (2012) 841-846,www.sciencedirect.com ( diakses 6 Juli 2017).

J.Akker, Principle and Methods of Development Research, Design Metodology and Development Research,(London: Kluwer,1999),h.16.

HuiweiCai .E - Learning and Teaching English . IERI Procedia 2 (2012) 841-846, www.sciencedirect.com ( accessed July 6 , 2017).

Sharon E, Smaldino,DeborahL.Lowtherdan James D.Russell, TeknologiPembelajarandan Media untukBelajar ( Jakarta: KencanaPrenadamedia Group, 2011), h.279.

SyaifulBahriDjamarah and Aswan Zain, StrategyLearnTeaching (Jakarta: RinekaCipta , 2002 ), p.10.

Tom Hutchinson dan Alan Waters, English for Specific Purposes A Learning-Centred Approach( Cambridge University Press, 1987), h.3.

YahyaDkhissi .English for SpecificAcademicPurposes: The Need for ICT and Reconstruction, Volume 14 Issue 6 Version 1.0 Year 2014, ( accessed July 7 , 2017).

I KomangPriatna, I Made Putramana, God GedeHendraDivayana . Development ofE-ModuleModelBasedLearningProject Based LearningInLessonVideographyforStudentClassXDesignVisualCommunicationat SMKNegeri1Sukasada, Journal National Education Technique Informatics (JANAPATI), Volume 6, Number 1, March 2017 ( accessed August 27 , 2017)

Vembriarto ,TeachingModule ( Yogyakarta: Foundation Paramita Education , 1981), p.13.

D. Purwanto ,TracesstepDevelopmentTechnologyEducationinIndonesia (Jakarta: Department Education National , 2005), p. 145.

J.Akker ,Principle and Methods of Development Research, DesignMethodologyand Development Research, ( London: Kluwer, 1999), p.16.

TienTein Lee, Kamisah Osman, Interactive Multimedia Module in the Learning of Electrochemistry;Effect on Students' Understanding and Motivation . Procedia -social and Behavioral Sciences 46 92012) 1323-1327. www.sciencedirect.com( accessed June 10th 2017). 
Tom Hutchinson dan Alan Waters.English for Specific Purposes (Cambridge: Cambridge University Press, 1987),hh.55-56.

Tim Program StudiPendidikanBiologiProfil Program

StudiPendidikanBiologiFakultasKeguruandanIlmuPendidikanUniversitasMuhammadiyah Palembang (Palembang: UniversitasMuhammadiyah Palembang,2012),h.3.

YusufhadiMiarso,MenyemaiBenihTeknologiPendidikan(Jakarta: Kencana,2004), h.149.

Sugiyono ,MethodResearchQuantitative qualitativeandR \& D ( Bandung: Alfabeta, 20 09 , p.134

YusufhadiMiarso ,SowingSeedTechnologyPEducation (Jakarta: Gold, 2004), h.149.

I KomangPriatna, I Made Putramana,DewaGede Hendra Divayana. Pengembangan E-ModulBerbasis Model Pembelajaran Project Based Learning Pada Mata PelajaranVideografiuntukSiswaKelas X DesainKomunikasi Visual di SMK Negeri 1 Sukasada, JurnalNasionalPendidikanTeknikInformatika (JANAPATI),Volume 6,Nomor 1, Maret 2017 (diakses 27 Agustus 2017) 